\title{
VIII
}

\section{A CASE OF MILIAN'S 9TH DAY ERYTHEMA}

By F. G. FOSTER, M.A., M.D.; D.P.H., M.O.V.D. Clinic, Birkenhead

THE Jarisch-Herxheimer reaction is not infrequently seen in Venereal Diseases Clinics in the course of antisyphilitic treatment, but the reaction known as Milian's 9th Day Erythema is a matter of rare occurrence.

The following case was an especially severe one and presents all the typical features of this latter reaction.

H. L. Keim in Arch. of Dermat. \& Syph., Chicago, Vol. 3I, No. 3, March, I935, writes :

"This is a morbilliform or scarlatiniform erythema which appears from 8-Io days after the first injection of Arsphenamine. It is a mild self-limited cutaneous lesion and not the serious vesiculo-erythro-dermia which eventuates in the crustaceous dermatitis, and which is probably due to a true intoxication with the arsenical radical. The characteristic features are sufficiently clear cut to distinguish the symptom-complex from other mild reactions to Arsphenamine.'

Ten cases were described, which, in his opinion, corroborated Milian's theory.

Stokes in "Modern Clinical Syphililogy," and Edition, states :

"These reactions are usually associated with a prodromal chill and fever which usually appears on the 7-I2th day after the institution of Arsphenamine treatment, thus presenting something apparently suggestive of an incubation period.

"The prodrome . . . consists of headache, backache, stiffness and malaise, sometimes with obstinate vomiting or diarrhœa.

"The differentiation from a cutaneous Herxheimer effect in early syphilis must be recalled. If fever lasts longer than I2 hours the Herxheimer effect is practically excluded."

Finally he remarks: "Some residual pigmentation or a slight furfuraceous desquamation may follow. There is sometimes œdema and the eyes may be swollen shut." 


\section{A CASE OF MILIAN'S 9TH DAY ERYTHEMA}

The patient who is the subject of the present report was W.M., aged twenty, a machine staker.

Coitus about the middle of May, I935. A penile sore appeared three weeks later for which he was treated by a doctor with some antiseptic lotion.

24.7.35. First attendance at V.D. Clinic.

Healed indurated sore in coronal sulcus ; shotty glands in groin and axillæ: post mastoid glands enlarged : maculopapular rash arms, legs, thighs and trunk: inflamed and boggy throat.

W.R. ++

Bismostab $\cdot 25 \mathrm{gm}$.

No Arsenic given as he had had a heavy tea.

29.7.35. Stabilarsan $\cdot 45$ gm., Bismostab $\cdot 25$ gm.

2.8.35. Stabilarsan $\cdot 45 \mathrm{gm}$., Bismostab $\cdot 25 \mathrm{gm}$.

7.8.35. Bright erythematous rash over trunk and arms.

Sickness, vomiting and headache.

Temp. roo. $6^{\circ} \mathrm{F}$.

Ametox $\cdot 60 \mathrm{gm}$.

8.8.35. Malaise still present. Temp. $99 \cdot 6^{\circ} \mathrm{F}$. Rash still bright. Ametox 60 gm.

9.8.35. Rash fading. Temp. $99^{\circ}$ F. Slight malaise.

I4.8.35. Rash still fading : feels fairly well.

Stabilarsan · 45 gm., Bismostab • 25 gm.

15.8.35. Sick headache. Temp. $99 \cdot 6^{\circ} \mathrm{F}$.

Face puffy. Urine-albumen +++ .

Refused in-patient treatment.

I6.8.35. Edema-face and both ankles. Temp. $99^{\circ} \mathrm{F}$.

Urine-albumen +++ . Refused inpatient treatment.

2I.8.35. Very extensive odema both ankles and legs : face puffy: eyelid swollen.

No sample of urine available.

Admitted to Municipal Hospital.

23.8.35. Municipal Hospital-œedema much diminished.

Urine-albumen-a trace.

Blood urea-34 $\mathrm{mg}$. 


\section{BRITISH JOURNAL OF VENEREAL DISEASES}

Non-protein nitrogen-35 $\mathrm{mg}$.

W.B.C. I5,000, mainly polymorphs.

25.8.35. No œdema.

Urine-no albumen.

Urea concentration test normal.

26.8.35. Stabilarsan $\cdot 45 \mathrm{gm}$.

31.8.35. Stabilarsan $\cdot 60$ gm.

Urine clear.

Discharged from hospital.

4.9.35-23.9.35. Attended Venereal Diseases Clinic twice weekly.

Course of Stabilarsan and Bismostab completed.

Faint blush still remains on trunk.

23.I0.35. W.R.-

Faint rash on trunk and elbows. Urine clear.

It is interesting to note that despite the fact that the urine was loaded with albumen and that there was extensive œdema of the face, legs and ankles, the condition cleared up after two days' rest in hospital without any special treatment beyond fluid diet. Further, the fact that the urea concentration and non-protein nitrogen tests were normal throughout proved that the condition was not due to a toxic nephritis.

The character of the rash, its first appearance on the ninth day after the first injection and the fact that continued arsenical treatment did not cause exfoliative dermatitis suggests a strong resemblance to Milian's 9th Day Erythema.

Its disappearance under further specific treatment seems to exonerate the drugs.

Colonel L. W. Harrison, to whose suggestions and help in the preparation of this article I am greatly indebted, agrees that the condition was probably a Milian's gth Day Erythema, but points out that a Jarisch-Herxheimer reaction, whilst commonest after the first, is by no means unknown after the second or third injection.

On the other hand, Stokes's dictum that if fever lasts longer than I2 hours the Herxheimer effect is practically excluded - and in this case it lasted for over a weekexcludes the probability of the reaction in this case being other than a Milian's 9th Day Erythema. 